\title{
Microcystin-LR Enrichment from Freshwater by a Recombinant Plant-derived Antibody Using Sol-Gel-Glass Immunoextraction
}

\author{
Anna-Cathrine Neumann,* Stanislav Melnik,** Reinhard NiesSner,* Eva Stoeger,** and \\ Dietmar KNOPP*广 \\ *Institute of Hydrochemistry, Chair of Analytical Chemistry, Technical University Munich, Marchioninistrasse 17, \\ 81377 Munich, Germany \\ **Department for Applied Genetics and Cell Biology, Molecular Plant Physiology and Crop Biotechnology, \\ University of Natural Resources and Life Sciences, Muthgasse 18, 1190 Vienna, Austria
}

\begin{abstract}
Eutrophication of water bodies can promote cyanobacterial (blue-green algae) blooms, which has become a source of increasing concern for both recreational and drinking water use. Many bacterial species can produce toxins that pose threats to wildlife, domestic animals and humans. Microcystin-leucine-arginine (MC-LR) is the most frequent and most toxic microcystin congener. For the first time, lab-scale investigations were performed to test the application of a recombinant plant-derived anti-MC-LR antibody immobilized on an immunoaffinity support material to selectively extract the toxin from spiked freshwater samples. As a comparison, its hybridoma-derived counterpart (murine monoclonal antibody) was evaluated. The antibody-doped material was prepared via an optimized sol-gel process; its stability and binding efficiency of MC-LR in spiked freshwater samples were thoroughly tested using the ELISA and orthogonal LC-MS methods. For removal, two column-based procedures with sequential or continuous cyclic sample addition and a suspension mode (moving adsorbent) were tested. Noteworthy the results obtained with a crude antibody fraction were fully compatible with the highly purified preparation. This study paves the way for further investigation being focused on novel applications of plant-derived anti-MC-LR antibodies in bioremediation to selectively deplete the toxin from freshwater: a green and promising technology without secondary pollution.
\end{abstract}

Keywords Cyanobacteria, freshwater systems, microcystin-LR (MC-LR), plant-derived antibody, immunoextraction, sol-gel material

(Received August 22, 2018; Accepted October 1, 2018; Advance Publication Released Online by J-STAGE October 12, 2018)

\section{Introduction}

The eutrophication of water bodies can promote cyanobacterial (blue-green algae) blooms, which is an increasing worldwide environmental problem. ${ }^{1-3}$ Many of the cyanobacterial species are able to produce potent cyanotoxins, for example microcystins (MCs), ${ }^{4}$ and pose threats to wildlife, domestic animals and humans. Because chronic exposure to even low concentrations of MCs may lead to unwanted side effects, a recommended guideline value of $1 \mu \mathrm{g} \mathrm{L}^{-1}$ for total MC-LR was established for drinking water, the primary source of exposure, by the World Health Organization. ${ }^{5}$ In addition, cyanotoxins in recreational bathing water may constitute an acute human health and safety hazard owing to inhalation and dermal contact.

To mitigate algal blooms, including cyanobacteria, algaecides like copper sulfate, copper chelates or oxidants like hydrogen peroxide can be applied to lakes and reservoirs. ${ }^{6,7}$ Commonly used methods for the removal of extracellular (dissolved) MCLR in drinking water can be separated into chemical oxidation (e.g. ozonation, chlorine and chlorine-based oxidants, potassium permanganate and potassium ferrate, or advanced oxidation

$\dagger$ To whom correspondence should be addressed.

E-mail: Dietmar.Knopp@ch.tum.de processes) $)^{8-16}$ and physical methods (e.g. mesoporous, granular or powdered activated carbon adsorption, graphene oxide, nanofiltration, giant reed-derived biochars, and amine/thiol containing organosilica). ${ }^{17-22}$ All of these methods are partially accompanied by disadvantages, like inefficiency, consumption of chemicals, formation of undesirable by-products, high maintenance costs, carbon-fouling effects and, above all, low selectivity for all mentioned techniques. ${ }^{12,23,24}$ Hence, new removal methods that can target toxic pollutants more specifically are urgently needed.

Higher selectivity can be obtained, e.g., using molecularly imprinted polymers (MIPs), which can be considered to be synthetic antibody-like materials. ${ }^{25}$ They are relatively easy to synthesize using either the complete target molecule, in this case MC-LR, ${ }^{26-31}$ or only a characteristic building block, e.g. L-arginine, as the template molecule. ${ }^{32}$ The main disadvantage is demand for a large amount of template to synthesize a bulk quantity of polymer. So far, only one paper has reported the application of MIPs for the removal of MC-LR from surface water in a lab-scale experiment. ${ }^{28}$

Another option is the use of biological receptors, although related applications to remove substances dangerous to health from water samples are not presently known. Obviously, the provision of larger quantities, i.e., gram to kilogram amounts of binders, is a bottleneck, since it is highly cost-intensive. 
This status could be significantly improved by transgenic expression of recombinant proteins using plants, owing to enormous advantages in economy and scalability. ${ }^{33-36}$ Undisputable, phytoremediation of contaminated soils and water that focus on hyperaccumulation of pollutants in above-ground tissues is a strongly researched topic. ${ }^{37,38}$ Recently, Madhurina et al. ${ }^{39}$ reported on phytoremediation of pharmaceutical wastewater using aquatic macrophyte Pistia stratiotes, known as water cabbage or water lettuce.

Genetic engineering can be a powerful strategy for enhancing the phytoremediation capabilities, e.g., by introducing genes into plants that may originate from microorganisms. ${ }^{40}$ However, the use of genetically engineered plants with extended remediation capabilities under surrounding conditions is variably restricted by national laws and provisions on an international scale. ${ }^{41,42}$ Therefore, the very few related studies that have become known were performed under strictly controlled conditions at the lab-scale. For the first time, Drake et al. ${ }^{43}$ stimulated extending phytoremediation capabilities of plants to environmental pollutants other than heavy metals by generating transgenic plants expressing an antibody specific to a particular chemical compound. They performed a feasibility study using hydroponic tobacco plant cultures expressing the murine monoclonal antibody Guy's13 as a model system. Later, this research group reported about the generation of transgenic tobacco plants expressing antibodies to the microcystin MC-LR based on mAb $3 \mathrm{~A} 8$, which was originally isolated from a naive human semisynthetic phage display library selected against MC-LR. ${ }^{44}$ The antibody, extracted from the leaves or rhizosecreted into hydroponic medium, was shown to have functional binding to the target analyte. In another study, the development of a surface-engineered strain of yeast, Pichia pastoris, was constructed, which displayed a functional protein on its surface that enabled binding of the phenolic xenoestrogen bisphenol A. ${ }^{45}$ Recently, Morath et al. ${ }^{46}$ described the functionalization of the moss Physcomitrella patens with extracellular catalytic and/or binding activities, which offered a potential for the removal of toxic compounds from wastewater.

An alternative option is the trapping of a chemical by (immuno)affinity support materials using purified antibodies. Immunoaffinity chromatography (IAC), also termed immunoaffinity solid-phase extraction (IA-SPE) or immunoaffinity extraction (IAE), is known to be one of the most powerful sample pretreatment techniques, and is based on the selective interaction of an immobilized antibody and its antigen. ${ }^{47,48}$ Different support materials and immobilization methods for the antibody are described. The immobilization under harsh conditions might lead to a partial loss of antibody functionality owing to random orientation or changes of the antibody's structure. ${ }^{49}$ A relatively gentle method for biomolecule immobilization is entrapment in a sol-gel-derived glass matrix. The porous glass is formed under mild conditions and the pore size can easily be tailored by controlling the aging time of the glass..$^{50-55}$

Recently, we reported on the generation, molecular characterization and application for ELISA and lateral-flow assay (LFD) of plant-derived anti-MC-LR antibody MC10E7 using tobacco plants. ${ }^{56}$ The plant-derived antibody was based on the murine mAb MC10E7, which was generated earlier. ${ }^{57}$ As a follow-up to these studies, the focus of the present manuscript is placed on investigations to test the analytical application of the plant-derived antibody in terms of a sol-gel immunoaffinity support material for removal of the toxicant from aqueous environmental samples in lab-scale experiments.

\section{Experimental}

\section{Reagents and chemicals}

Potassium hydrogen phosphate $\left(\mathrm{K}_{2} \mathrm{HPO}_{4}\right)$, potassium dihydrogen phosphate $\left(\mathrm{KH}_{2} \mathrm{PO}_{4}\right), 3,3^{\prime}, 5,5^{\prime}$-tetramethylbenzidine (TMB), hydrogen peroxide $\left(\mathrm{H}_{2} \mathrm{O}_{2}, 33 \%\right)$, sodium azide $\left(\mathrm{NaN}_{3}\right)$, potassium sorbate $\left(\mathrm{C}_{6} \mathrm{H}_{7} \mathrm{KO}_{2}\right)$, sodium carbonate $\left(\mathrm{Na}_{2} \mathrm{CO}_{3}\right)$, casein from bovine milk, methanol $(\mathrm{MeOH})$, acetonitrile $(\mathrm{ACN})$, dimethyl sulfoxide (DMSO), tetramethyl orthosilicate (TMOS), glycerol, hydrochloric acid, sulfuric acid and HRP-labeled antihuman IgG antibody ( $\mathrm{Fc}$ specific, produced in goat) were purchased from Sigma-Aldrich (Taufkirchen, Germany). Potassium dihydrogen citrate $\left(\mathrm{C}_{6} \mathrm{H}_{7} \mathrm{KO}_{7}\right)$ was from Alfa-Aesar (Karlsruhe, Germany). Sodium hydrogen carbonate $\left(\mathrm{NaHCO}_{3}\right)$ and magnesium chloride $\left(\mathrm{MgCl}_{2}\right)$ were obtained from Merck (Darmstadt, Germany). Sodium hydroxide $(\mathrm{NaOH})$ and sodium chloride $(\mathrm{NaCl})$ were purchased from Carl Roth (Karlsruhe, Germany). Ammonium sulfate $\geq 99.5 \%$ was purchased from Merck (Darmstadt, Germany), ethylenediaminetetraacetic acid (EDTA) $\geq 99 \%$ from Carl Roth (Karlsruhe, Germany), and phenylmethanesulfonyl fluoride (PMSF) $\geq 98.5 \%$ from SigmaAldrich (Steinheim, Germany). Pure microcystin-LR (MC-LR) $\left(\geq 95 \%\right.$, molecular weight $\left(M_{\mathrm{W}}\right.$, HPLC, $\left.=995.2 \mathrm{~g} \mathrm{~mol}^{-1}\right)$ was purchased from Enzo Life Science (Lörrach, Germany). The mouse monoclonal antibody (murine antibody) against MC-LR (anti-MC-LR, clone MC10E7) was produced by a hybridoma clone (protein A/G purified). ${ }^{57}$ The recombinant chimeric version of MC10E7 (plant-derived MC10E7) was produced in tobacco plants and purified as described recently. ${ }^{56}$ To obtain a crude antibody preparation from tobacco, transformed leaf tissue was frozen in liquid nitrogen and ground to a fine powder. The latter was mixed with an extraction buffer (PBS pH 7.4 containing $5 \mathrm{mM}$ EDTA and $0.2 \mathrm{mM}$ PMSF) at a $1: 1(\mathrm{w} / \mathrm{v})$ ratio, and the mixture was homogenized using ultrasound. Homogenates were shaken at $4^{\circ} \mathrm{C}$ for $1 \mathrm{~h}$, followed by removal of cell debris by centrifugation at $9000 \mathrm{~g}$ for $20 \mathrm{~min}$ at $4^{\circ} \mathrm{C}$. The

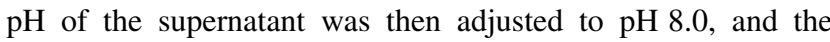
centrifugation step was repeated. In order to precipitate the antibody, solid ammonium sulfate was slowly added to the stirred clarified lysate to $45 \%$ saturation at $4{ }^{\circ} \mathrm{C}$ and left on a stirrer overnight at this temperature. Precipitated proteins were collected by centrifugation at $9000 \mathrm{~g}$ for $30 \mathrm{~min}$ at $4{ }^{\circ} \mathrm{C}$ and the pellet was washed once with a small amount of cold ammonium sulfate solution $\left(50 \%\right.$ saturation at $\left.4^{\circ} \mathrm{C}\right)$ followed by centrifugation.

The HRP-labeled anti-mouse IgG antibody $(\mathrm{H}+\mathrm{L}$, produced in horse, affinity purified) was obtained from Axxora (Lörrach, Germany). Ultrapure water was produced using reverse osmosis with UV treatment (Milli-RO 5 Plus, Milli-Q185 Plus, Millipore, Eschborn, Germany). The microtiter plates (Microlon, Cat. No. 655061; high binding capacity) were obtained from Greiner bio-one, Frickenhausen, Germany. The plates were washed automatically with a 96-channel plate washer (ELx405 Select) and the absorption was measured with a microtiter plate reader (Synergy HT), both from Bio-Tek (Bad Friedrichshall, Germany).

\section{Preparation of sol-gel glass immunoaffinity extraction columns (SGG-IAE)}

The antibody functionalized support material was prepared by a two-step sol-gel microencapsulation procedure in silica-based material according to Degelmann et al..$^{54}$ with minor modifications. A silica sol was prepared by the addition of $250 \mu \mathrm{L}$ dest. $\mathrm{H}_{2} \mathrm{O}, 300 \mu \mathrm{L}$ glycerol/water $(1: 1$, v/v), $100 \mu \mathrm{L}$ 
$\mathrm{MeOH}, 100 \mu \mathrm{L} 40 \mathrm{mM} \mathrm{HCl}$ and $1.7 \mathrm{~mL}$ TMOS to a glass tube and mixing for $15 \mathrm{~min}$ under ice cooling and stirring. The antibody was diluted in phosphate-buffered saline $(1 \mathrm{mM}$ $\mathrm{KH}_{2} \mathrm{PO}_{4}, 70 \mathrm{mM} \mathrm{K} \mathrm{HPO}_{4}, 14.5 \mathrm{mM} \mathrm{NaCl}, \mathrm{pH} 7.4, \mathrm{PBS}$ ) in a petri dish $(35 \times 10 \mathrm{~mm})$ to give a final concentration of $1 \mathrm{mg} \mathrm{mL}^{-1}$. An equal volume of the silica sol was added to the antibody solution and immediately mixed. The sol-gel ageing preceded at $4{ }^{\circ} \mathrm{C}$ for $24-48 \mathrm{~h}$ until a weight loss in the range between 46 and $50 \%$ was obtained. The transparent glass matrix was ground with a mortar, sieved (mesh size: $250 \mu \mathrm{m}$ ), transferred to empty glass columns (LiChrolut, $3 \mathrm{~mL}$, Merck, Darmstadt) and equipped with PTFE frits (LiChrolut, Merck) below and above the glass matrix. The column was directly flushed with $3 \mathrm{~mL}$ of PBS twice at a flow-rate of $0.5 \mathrm{~mL} \mathrm{~min}^{-1}$ and liquid flow tested for the presence of non-encapsulated antibody by indirect non-competitive ELISA. The IAE-columns were stored at $4^{\circ} \mathrm{C}$ in PBS until utilization. For control, additional columns were prepared by using sol-gel materials obtained by the same procedure, but without any antibody addition (blank columns).

\section{Estimation of antibody amount immobilized on the SGG-IAE support}

Generally, IAE-supports with high analyte binding capacity are desirable. To get a first estimate of the theoretical maximum binding, the amount of antibody in the flow-through fraction obtained by flushing the newly prepared column with PBS and caused by the minor leakage of insufficiently entrapped antibodies has to be determined. The commonly used techniques for the colorimetric detection and quantification of proteins do not provide the required sensitivity and are typically not useful. Assuming much lower antibody concentrations in the eluate, the quantification was done by an indirect non-competitive ELISA using eluate fractions as the potential antibody source. The calibration was performed with dilutions of mAb MC10E7 in the range between 1.39 and $1109 \mathrm{ng} \mathrm{mL}^{-1}$. In all experiments, when entrapping $0.5 \mathrm{mg}$ of antibody, the leached protein was $<15 \mu \mathrm{g}$ in a total wash volume of $6 \mathrm{~mL}$, which corresponds to $<3 \%$ of the overall used antibody amount. This finding is in accordance with earlier reports on antibody-functionalized SGG-IAC supports, which showed negligible leaching. ${ }^{58,59}$

\section{Immunoaffinity extraction (IAE)-procedures}

Three different extraction modes were tested (Fig. 1). Besides two column-based procedures, which were performed with sequential (mode A) or continuous cyclic sample addition (mode B), the suspension extraction (moving adsorbent) (mode C) was applied. Unless indicated otherwise, in modes A and B, all solutions were added by a peristaltic pump at a flow rate of $0.5 \mathrm{~mL} \mathrm{~min}^{-1}$. The used amounts of sol-gel were at least $0.5 \mathrm{~g}$, and for larger bed volumes were linearly scaled up. The IAE columns were first equilibrated to room temperature (RT) followed by conditioning twice with $3 \mathrm{~mL}$ of the sample media $(\mathrm{MeOH} /$ water 10:90, v/v). The samples were spiked with a MC-LR stock solution ( $1 \mathrm{mg} \mathrm{mL}^{-1}$ in ACN, 9\% DMSO) at different initial concentration (50 or $100 \mathrm{ng} \mathrm{mL}^{-1}$ ) and flushed stepwise in 1-mL fractions manually (mode A) and flow-through fractions were collected. Next, a washing step was performed, as described above, followed by the elution of MC-LR with ACN/water (70:30, v/v). In mode B, the water sample was stirred with a magnetic stirrer (100 rpm) and continuously flown over the IAE-column for 18 to $25 \mathrm{~h}$. At hourly intervals $100-\mu \mathrm{L}$ aliquots of water were taken for the determination of MC-LR. In mode $\mathrm{C}, 2.5 \mathrm{~g}$ of sol-gel (particle size $<250 \mu \mathrm{m}$ ) was added to $1 \mathrm{~L}$ of water which was spiked at $25 \mu \mathrm{g} \mathrm{L}^{-1}$ with MC-LR.

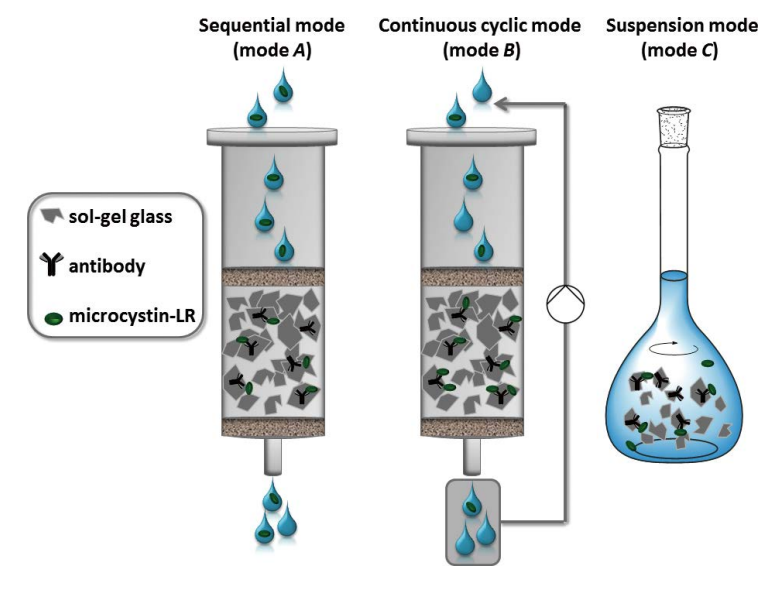

Fig. 1 Three different extraction modes: Beside two column-based procedures which were performed with sequential (mode A) or continuous cyclic sample addition (mode B), the suspension extraction (moving adsorbent) (mode C) was applied.

The suspension was stirred for $25 \mathrm{~h}$ and $100-\mu \mathrm{L}$ aliquots of water were taken and analyzed, as described below. All experiments were conducted at RT.

\section{Freshwater sampling}

Surface-water samples were collected from two lakes and one river near Munich (Germany). The $\mathrm{pH}$ values were determined, being 8.0 for lake Starnberger See (sampling point Kempfenhausen), 8.1 for lake Ammersee (sampling point Eching) and river Windach (sampling point Windach). All water samples were filtered on a glass microfiber filter (Whatman Cat. No. 1822 047, Dassel, Germany) to remove particles larger than $1.2 \mu \mathrm{m}$ and were stored at $4^{\circ} \mathrm{C}$.

\section{Liquid chromatography/mass spectrometry (LC-MS)}

MC-LR was determined quantitatively using a Thermo Finnigan Surveyor HPLC system and an Orbitrap-based Exactive Benchtop mass spectrometer equipped with an electrospray ionization source (ESI) (Thermo Fisher Scientific, Bremen, Germany). Chromatographic separation was performed using a Hypersil GOLD reversed phase column $(2.1 \times 100 \mathrm{~mm}$, $1.9 \mu \mathrm{m}$ particle size, Thermo Fisher) in a column oven at $30^{\circ} \mathrm{C}$ (Hotdog 5090, ProLab, Reinach, Switzerland). Sample injection volumes were $10 \mu \mathrm{L}$ with a flow rate of $0.2 \mathrm{~mL} \mathrm{~min}^{-1}$. The mobile phase A was water and the mobile phase $\mathrm{B}$ was $\mathrm{MeOH}$, both containing $0.1 \% \quad \mathrm{NH}_{4} \mathrm{OH}$. Gradient elution was A/B of 75:25 (v/v) to $30: 70(\mathrm{v} / \mathrm{v})$ in $12 \mathrm{~min}$, then keeping constant for $1 \mathrm{~min}$, decreasing to initial $25 \% \mathrm{~B}$ in $1 \mathrm{~min}$ and maintaining at 25\% B for another minute. Mass spectra were obtained in the negative ion mode, which yielded a higher signal-to-noise ratio than the positive mode. MC-LR was identified by its retention time of $9.2 \pm 0.3 \mathrm{~min}$ and its exact mass $[\mathrm{M}-\mathrm{H}]^{-}=993.54149$. An accuracy of $\pm 5 \mathrm{ppm}$ was acceptable. The calibration was done in triplicate by measuring standards in the range of $2-400 \mu \mathrm{g} \mathrm{L}^{-1}$ in $\mathrm{MeOH} /$ water (50:50, v/v) (correlation coefficient $R=0.999, m=3, n=7$ ). Leucin-enkephalin (Cat. No. L9133, Sigma-Aldrich) was used as internal standard.

\section{Indirect competitive ELISA}

Because of a high sample load, the lower cost and less timeconsuming, indirect ELISA was used for the determination of MC-LR in all IAE-eluate fractions. No special sample purification step was required. To prove the reliability of the 


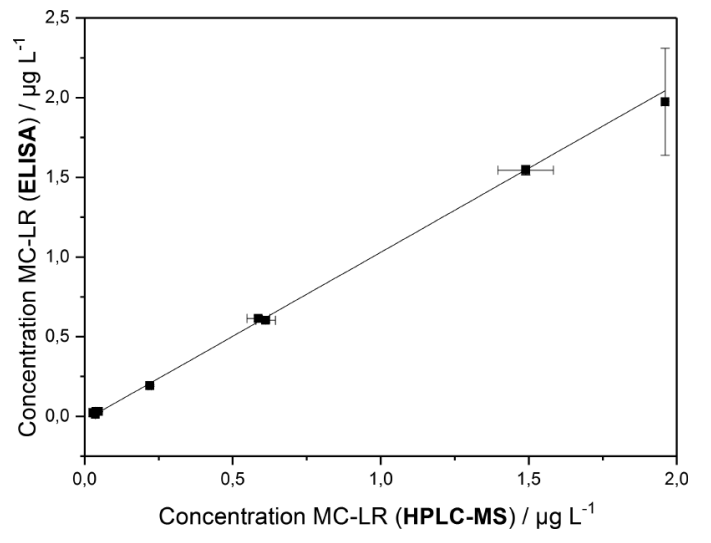

Fig. 2 Comparison of ELISA and HPLC-MS for the determination of MC-LR standard samples (MeOH/water (10:90, v/v); $n=9, m=3)$.

ELISA, a statistical evaluation was done by the determination of a set of different samples (flow-through, washing, elution) using ELISA and orthogonal LC-MS. When plotting the concentrations of MC-LR, determined by ELISA vs. the concentrations determined by LC-MS, a high correlation between the two methods was obtained (slope of $1.056 \pm 0.01$; $p$-level of 0.91 from a paired $t$-test, assuming a level of significance of $p \leq 0.05$ ) (Fig. 2).

For ELISA, transparent microtiter plates with 96 flat-bottom wells were used. Adhesive plate sealing film was obtained from Carl Roth (Karlsruhe). Buffers and solutions were prepared freshly with ultrapure water. Coating buffer $(\mathrm{pH} 9.6)$ consisted of $1.6 \mathrm{~g} \mathrm{Na}_{2} \mathrm{CO}_{3}, 2.9 \mathrm{~g} \mathrm{NaHCO}_{3}$, and $0.2 \mathrm{~g} \mathrm{NaN}_{3}$ in $1 \mathrm{~L}$ of water. For preparation of phosphate buffered saline (PBS, pH 7.6) $1.4 \mathrm{~g} \mathrm{KH}_{2} \mathrm{PO}_{4}, 12.2 \mathrm{~g} \mathrm{~K}_{2} \mathrm{HPO}_{4}$, and $8.5 \mathrm{~g} \mathrm{NaCl}$ were dissolved in $1 \mathrm{~L}$ of water. Blocking reagent was a freshly prepared solution of $1 \%(\mathrm{w} / \mathrm{v})$ casein in PBS. Washing buffer was PBST (PBS with $0.05 \%(\mathrm{v} / \mathrm{v})$ Tween 20$)$. The substrate buffer ( $\mathrm{pH}$ 3.8) was prepared with $46.0 \mathrm{~g} \mathrm{C}_{6} \mathrm{H}_{7} \mathrm{KO}_{7}$ and $0.1 \mathrm{~g}$ $\mathrm{C}_{6} \mathrm{H}_{7} \mathrm{KO}_{2}$ in $1 \mathrm{~L}$ of water. The substrate solution consisted of $25 \mathrm{~mL}$ of substrate buffer, $500 \mu \mathrm{L}$ of a TMB stock solution (375 mg of TMB dissolved in $30 \mathrm{~mL}$ of DMSO), and $100 \mu \mathrm{L}$ of $1 \%$ hydrogen peroxide. The stop solution was $5 \% \mathrm{H}_{2} \mathrm{SO}_{4}$. The microtiter plates were coated with the MC-LR-BSA conjugate (50 ng mL $\mathrm{m}^{-1}$ in coating buffer, $200 \mu \mathrm{L} /$ well; coating buffer of $\mathrm{pH} 9.6$ consisted of $1.6 \mathrm{~g} \mathrm{Na}_{2} \mathrm{CO}_{3}, 2.9 \mathrm{~g} \mathrm{NaHCO}_{3}$ and $0.2 \mathrm{~g}$ $\mathrm{NaN}_{3}$ in $1 \mathrm{~L}$ of water) over night at $4^{\circ} \mathrm{C}$. (Note: The conjugate was prepared via a Michael addition, yielding a coupling rate of 3 microcystin residues per mole of protein. The details are described in Neumann et al. $)^{60}$ Further steps were performed at RT. The wells were washed automatically with a washing buffer and blocked with casein $(300 \mu \mathrm{L} /$ well $)$ for $1 \mathrm{~h}$ on an orbital shaker at $200 \mathrm{rpm}$. For the construction of calibration curves, the MC-LR stock solution ( $1 \mathrm{mg} \mathrm{mL}^{-1}$ in ACN/DMSO, 91:9, $\mathrm{v} / \mathrm{v})$ was diluted in $\mathrm{MeOH} /$ water $(10: 90, \mathrm{v} / \mathrm{v})$ to final standard concentrations in the range between 0.0001 and $100 \mu \mathrm{g} \mathrm{L}^{-1}$. After another washing step, the competition was carried out by the addition of a standard solution $(100 \mu \mathrm{L} /$ well $)$ or sample and same volume of anti-MC-LR antibody $\left(5 \mathrm{ng} \mathrm{mL}^{-1}\right.$ for $\mathrm{mAb}$ MC10E7) and incubating for $1 \mathrm{~h}$ under shaking. After washing, $200 \mu \mathrm{L}$ of a secondary HRP-labeled antibody were added to each well $\left(1.76 \mu \mathrm{g} \mathrm{mL}^{-1}\right.$ anti-mouse-HRP in PBS) and incubated for $1 \mathrm{~h}$ under shaking. After the last washing step, $200 \mu \mathrm{L} /$ well of the substrate solution were added, and the plate was shaken for about $15 \mathrm{~min}$. The enzyme based reaction was stopped by addition of $100 \mu \mathrm{L} /$ well of $5 \% \mathrm{H}_{2} \mathrm{SO}_{4}$ solution and the absorbance was read with a reader at $450 \mathrm{~nm}$. All measurements were performed at least in triplicate. For evaluating the results, a sigmoidal calibration curve was set up using Rodbard's fourparameter function, and the absorbance was plotted against the log concentration of MC-LR standards.

When the ELISA was used for quantification of the amount of primary antibody which was leached from the SGG-IAE column, it was performed in non-competitive format, i.e. without addition of MC-LR standards. In detail, primary antibody calibration solutions were prepared in the range of 1.39 to $1109 \mathrm{ng} \mathrm{mL}^{-1}$ in PBS and added to the plate $(200 \mu \mathrm{L} /$ well $)$. The samples (column fractions) were added at different dilutions (undiluted to 500-fold diluted; $200 \mu \mathrm{L} /$ well) to different wells. The other ELISA conditions were kept constant.

\section{Results and Discussion}

\section{Characterization of the sol-gel matrix}

The preparation of biologically doped materials via the sol-gel process is based on the growth of polymer chains around the biomolecules, thus maintaining to a great extent their active conformation within the matrix. The process can be carried out in aqueous solution where mild hydrolysis of precursor, mostly a silica alkoxide, and followed condensation-polymerization in presence of the biomolecule occur at ambient temperature. Depending on the ageing time, further condensation and dehydration of the wet gel occurs, which results in shrinkage of the polymer and collapse of its porous structure. Each step can be controlled independently and optimized for specific needs. For example, the pore size of the matrix can be controlled to obtain pores large enough to allow ligands diffuse to the biomolecules, but sufficiently small to keep the latter entrapped in a cage-like manner. Figure $3 \mathrm{~A}$ shows a SEM image of a sol-gel matrix synthesized in this study. It can be suggested, that the gel is characterized by a globular structure on a larger length scale and a hierarchical morphology in which small nanometer-sized globules are organized into larger ones, and thus forming a porous network. Quantitative determinations of pore size distribution and surface area can be derived using nitrogen adsorption-desorption measurements (Fig. 3B). For the above-described gel characteristic type IV adsorption isotherms were obtained and an $\mathrm{H} 1$ hysteresis loop, characteristics of mesoporous materials with pore diameter of 20 - $500 \AA$ and with high surface area of $\sim 500 \mathrm{~m}^{2} \mathrm{~g}^{-1}$.

\section{Optimization of SGG-IAE support preparation and binding} efficiency

The optimization of IAE performance was conducted using $\mathrm{mAb} \mathrm{MC} 10 \mathrm{E} 7$ and MC-LR spiked pure water $(\mathrm{MeOH} /$ water, 10:90, v/v). The SGG-ageing process directly correlates with the pore size, i.e., the higher the weight loss of the glass, the smaller the pores. For example, a $76 \%$ weight loss gave 5 times lower MC-LR extraction efficiencies. This might be due to reduced bioligand accessibility or decreased bioactivity of the antibodies owing to limited sterical flexibility within the pores. The highest extraction efficiencies, as expression of the binding capacity of the IAE-column, were gained when the weight loss was in the range between 46 and 50\%. Another important parameter is the antibody/SGG-matrix ratio. In the present study, the binding capacity was defined as the percentage ratio of the mass $(m)$ of MC-LR bound and the calculated maximum possible mass: 

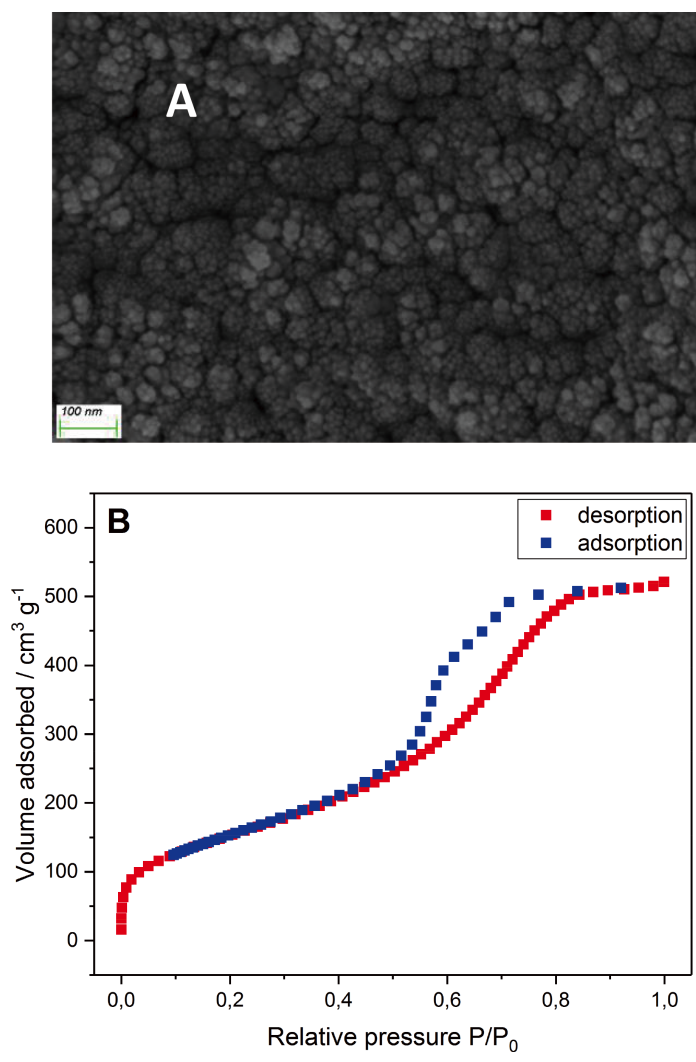

Fig. 3 (A) SEM image of the sol-gel matrix prepared by two-step acid-catalyzed hydrolysis of TMOS followed by ageing at $4^{\circ} \mathrm{C}$ for $\sim 48 \mathrm{~h}$ (weight loss $46 \%$ ); magnification $=150.00 \mathrm{KX}$, high voltage $=$ $5.00 \mathrm{kV}$, aperture size $=30.00 \mu \mathrm{m}$, working distance $=5.3 \mathrm{~mm}$. (B) Nitrogen adsorption-desorption isotherm of mesoporous silicate material. Conditions: $2 \mathrm{~h}$ evacuation at $25^{\circ} \mathrm{C}$, sample temperature during measurement $-196^{\circ} \mathrm{C}$, adsorption pressure 720 Torr.

$$
\text { Binding capacity }=\frac{m(\text { MC-LR bound })}{m(\text { MC-LR maximum possible mass })} \times 100(\%) .
$$

The calculation is based on the assumption of bivalent binding of the antibodies, the accessibility of all paratopes and at most bioactivity of immobilized antibodies. For example, $500 \mu \mathrm{g}$ of MC10E7 can theoretically bind $6.63 \mu \mathrm{g}$ of MC-LR, which corresponds to $100 \%$ binding capacity. In this study, different antibody amounts in the range between 50 and $500 \mu \mathrm{g}$ were entrapped each in a total amount of $0.5 \mathrm{~g}$ SGG (adjusted weight loss 50\%). The packed columns were examined by using frontal analysis, i.e., sequential addition of $1-\mathrm{mL}$ aliquots, altogether $10 \mathrm{~mL}$, of toxin standard $\left(663 \mu \mathrm{g} \mathrm{L}^{-1}\right.$, in $\mathrm{MeOH} /$ water $(10: 90$, $\mathrm{v} / \mathrm{v})$ ) and incubation for $5 \mathrm{~min}$ in order to meet the thermodynamic equilibrium, followed by monitoring the amount of MC-LR exiting from the column in the effluent. In parallel, also the non-specific binding (NSB) of MC-LR was determined via loading the toxin to a blank IAE-column (devoid of antibodies). With the highest antibody amount, $4.28 \mu \mathrm{g}$ of the loaded toxin was retained on the column. Concluding, under the equilibrium conditions an exceptionally high binding of almost $65 \%$ of the theoretical binding capacity was obtained and the NSB of toxin to SGG-matrix of $<10^{-4} \%$ (w/w) could be kept rather low.

\section{Elution, recovery and column regeneration}

In the case that the IAE-support material should be used
Table 1 Recovery of MC-LR from IAE-columns which were used for enrichment of MC-LR from spiked freshwater samples $\left(663 \mu \mathrm{g} \mathrm{L}^{-1} ; 10 \mathrm{~mL}\right)$ and eluted with $15 \mathrm{~mL}$ of ACN/water (70:30, $\mathrm{v} / \mathrm{v})$

\begin{tabular}{lccc}
\hline \multicolumn{1}{c}{ Sample } & $\begin{array}{c}\text { MC-LR } \\
\text { bond } / \mu \mathrm{g}\end{array}$ & $\begin{array}{r}\text { MC-LR } \\
\text { elute } / \mu \mathrm{g}\end{array}$ & $\begin{array}{c}\text { Recovery, } \\
\%\end{array}$ \\
\hline $\begin{array}{l}\text { Starnberger See } \\
\text { Ammersee }\end{array}$ & 4.3 & 3.8 & 88.4 \\
MeOH/dest. water (10:90, v/v) & 4.6 & 3.5 & 76.1 \\
\hline
\end{tabular}

a. Calculated by subtraction of the amount of MC-LR determined in the percolated sample from known loaded mass. IAE-columns contained $0.5 \mathrm{~g}$ of SGG-IAE-support $(0.5 \mathrm{mg}$ of plant-derived MC10E7).

repeatedly, there is a need for reversible binding and regeneration. This can be achieved by temporarily lowering the binding strength of the antibody to the target analyte. In preliminary experiments, a set of common elution methods including acidic buffer, organic modifier and chaotropic agents like glycin- $\mathrm{HCl}$ (" $a$ ": $0.1 \mathrm{M}$, pH 3.0 or " $b$ ": $0.1 \mathrm{M}$ glycin-HCL, $0.1 \mathrm{M} \mathrm{NaCl}$, $0.1 \%$ SDS, pH 3.0), ACN/water (70:30, v/v), MeOH/water (50:50, v/v), $\mathrm{MgCl}_{2}$ (3 M, $75 \mathrm{mM}$ HEPES), and $\mathrm{NaOH}(2 \mathrm{mM})$ to eluate MC-LR from mAb M10E7-immobilized IAE-columns was tested. Very low recovery $<10 \%$ were obtained with glycin$\mathrm{HCl}$ (buffer " $a$ "), $\mathrm{MgCl}_{2}$ and $\mathrm{MeOH} /$ water emphasizing a very strong binding by high affine antibodies. Only ACN/water and glycin- $\mathrm{HCl}$ (buffer " $b$ ") gave reasonable recoveries of $>70 \%$. Owing to possible disturbing ELISA or LC-MS determination, caused by a higher salt content and the presence of a detergent, the organic modifier was tested using spiked surface-water samples and plant-derived MC10E7-immobilized IAE-support (Table 1). The results clearly demonstrate the need for a high organic solvent content and larger volumes of the eluent for acceptable toxin elution, i.e., harsher conditions to impair the antibody-MC-LR interaction. While this might interfere with multiple use of the IAE-material, it does not constitute a problem for single-use applications, e.g., efficient removal of the toxin from contaminated aqueous samples.

\section{Investigation of possible matrix interferences}

When the immunoaffinity support should be applied for much larger volumes of samples, investigations to uncover interferences by possible matrix constituents are indispensable. With surface water, the presence of an organic material, like humic acids and chaotropic ions, e.g. calcium and to a lesser extent magnesium, dependent on their concentrations, may disturb the antibodies' activity. The indirect competitive MC-LR-ELISA test was performed and the obtained $\mathrm{IC}_{50}$ values used as a parameter to assess the influence of these substances on the antibody-analyte interaction. The plant-derived MC10E7 was stable up to a $\mathrm{Ca}^{2+}$ ion concentration of $65 \mathrm{mg} \mathrm{L}^{-1}$ and a humic acid concentration of $40 \mathrm{mg} \mathrm{L}^{-1}$, which is comparable to the murine antibody MC10E7. Furthermore, freshwater samples from two lakes near Munich (Starnberger See and Ammersee), and river Windach to be used as a model for initial experiments, were analyzed for calcium and dissolved organic carbon (DOC) content. The $\mathrm{Ca}^{2+}$ ion concentration was $41.5 \pm 0.5 \mathrm{mg} \mathrm{L}^{-1}$, $54.4 \pm 0.23 \mathrm{mg} \mathrm{L}^{-1}$ and $59.3 \pm 0.17 \mathrm{mg} \mathrm{L}^{-1}$ and the DOC was $4.60 \pm 0.00 \mathrm{mg} \mathrm{L}^{-1}, \quad 5.10 \pm 0.01 \mathrm{mg} \mathrm{L}^{-1}$ and $7.34 \mathrm{mg} \mathrm{L}^{-1}$ for Starnberger See, Ammersee and Windach, respectively. Based on these values no inhibitory effects of surface-water samples were expected during depletion experiments. 


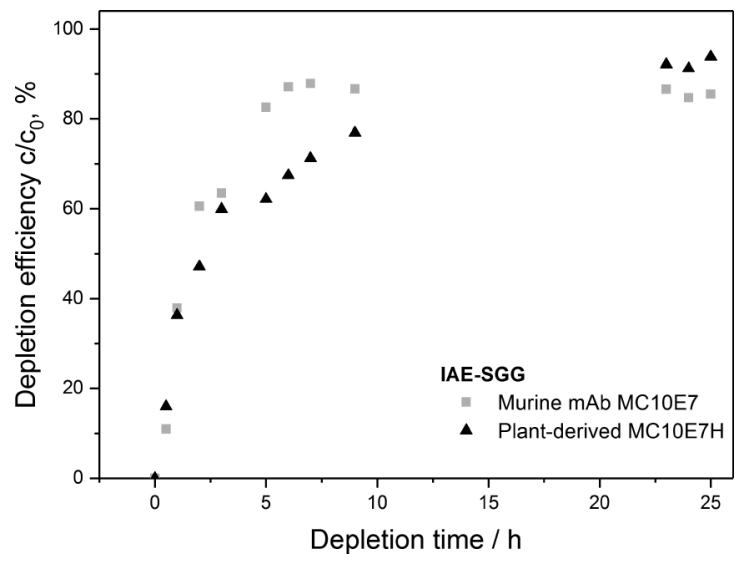

Fig. 4 Continuous cyclic sample addition depletion (mode B) of MC-LR from a spiked freshwater sample (Starnberger See, $40 \mathrm{~mL}$, $104 \mu \mathrm{g} \mathrm{L}^{-1} \mathrm{MC}-\mathrm{LR}$ ) over $25 \mathrm{~h}$ with SGG-entrapped murine and plantderived MC10E7 antibodies (for each antibody: $0.5 \mathrm{mg} \mathrm{mAb}$ in $0.5 \mathrm{~g}$ SGG).

Removal of MC-LR from freshwater samples: Tests with affinity purified murine and plant-derived MC10E7 antibodies

To monitor the removal rate of MC-LR from freshwater, 40-mL samples from Starnberger See and Ammersee were spiked at 100 and $104 \mu \mathrm{g} \mathrm{L}^{-1}$, respectively, and submitted to continuous cyclic sample addition (mode B); $100-\mu \mathrm{L}$ aliquots of water were collected at different time intervals over $25 \mathrm{~h}$ and the remaining toxin concentration in the samples determined by ELISA (Fig. 4). The removal efficiency was defined as the percentage ratio of the mass $(m)$ of MC-LR bond and the mass of MC-LR added:

$$
\text { Depletion efficiency }=\frac{m(\text { MC-LR bound })}{m(\text { MC-LR added })} \times 100 \%
$$

The result is comparable for both antibodies over the first $4 \mathrm{~h}$. Minor differences are visible in the area between 60 to $80 \%$, i.e., a slightly delayed saturation with the plant-derived antibodyencapsulated IAE-column. Most probably, this could be attributed to its slightly higher $K_{\mathrm{D}}$-value compared to the murine antibody. ${ }^{56}$ While maximum removal of the toxin was reached for the latter already after about $7 \mathrm{~h}$, it was delayed in time for the plant-derived antibody. Nevertheless, with both surface water samples the removal efficiency after $25 \mathrm{~h}$ was $\sim 81$ and $95 \%$ for murine and plant-derived antibodies, respectively (Table 2).

Measures to accelerate the removal process were focused on favoring mass-transfer and probability of antibody-analyteinteraction by suspension of SGG-particles $(<250 \mu \mathrm{m})$ in microcystin-contaminated freshwater (river Windach) under stirring (mode C). To compare with previous continuous cyclic sample addition (mode B), the higher mass of $2.5 \mathrm{~g}$ of IAEsupport was used as the total amount of MC-LR to be enriched from the water sample was increased proportionally. As expected, a much faster removal rate was observed (Fig. 5). Already after the first hour, 72 and $82 \%$ of the microcystin were depleted from the water sample using affinity support based on murine or plant-derived antibody, respectively. The saturation was almost complete after only $5 \mathrm{~h}$ depletion time. Surprisingly, on average a $20 \%$ higher binding capacity was observed compared to continuous cyclic mode (Table 3 ). Most probably, this should not be attributed to a higher biological activity of the
Table 2 Extraction using continuous cyclic sample addition over $25 \mathrm{~h}$ (mode B) of MC-LR from spiked freshwater samples (Starnberger See and Ammersee at 100 and $104 \mu \mathrm{g} \mathrm{L}^{-1}$, respectively; $40 \mathrm{~mL}$ )

\begin{tabular}{|c|c|c|c|c|}
\hline Antibody & Sample & $\begin{array}{c}\text { Depletion } \\
\text { efficiency, } \\
\%\end{array}$ & $\begin{array}{c}\text { Binding } \\
\text { capacity }^{\mathrm{a}}, \\
\%\end{array}$ & $\begin{array}{c}\text { MC-LR } \\
\text { bond } / \\
\mu \mathrm{g}\end{array}$ \\
\hline Murine MC10E7 & Starnberger See & 85 & 47 & 3.4 \\
\hline Murine MC10E7 & Ammersee & 77 & 44 & 3.2 \\
\hline $\begin{array}{l}\text { Plant-derived } \\
\text { MC10E7 }\end{array}$ & Starnberger See & 95 & 53 & 3.8 \\
\hline $\begin{array}{l}\text { Plant-derived } \\
\text { MC10E7 }\end{array}$ & Ammersee & 96 & 54 & 4.0 \\
\hline Blank $^{c}$ & Ammersee & 7 & - & 0.3 \\
\hline
\end{tabular}

a. Binding capacity compared to the theoretical maximum binding capacity.

b. MC-LR bond at the IAE-column ( $0.5 \mathrm{~g}$ of SGG-IAE-support with $0.5 \mathrm{mg}$ of immobilized antibody MC10E7).

c. Non-specific binding at blank SGG.

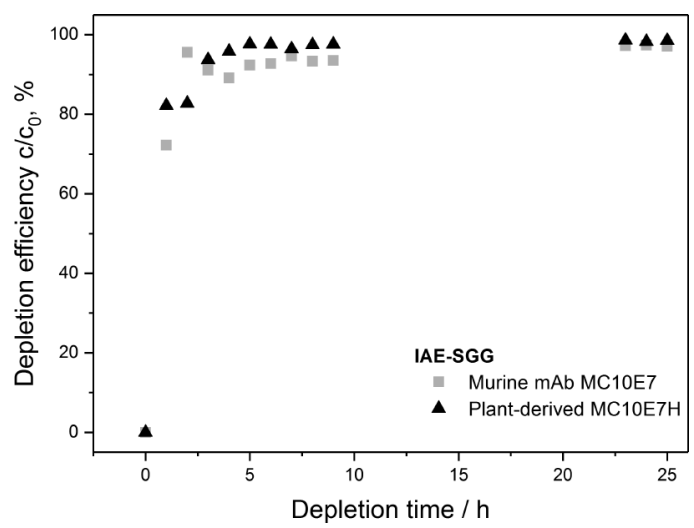

Fig. 5 Suspension depletion (mode C) of MC-LR from a spiked surface water sample (river Windach, $1 \mathrm{~L}, 25 \mu \mathrm{g} \mathrm{L}^{-1} \mathrm{MC}-\mathrm{LR}$ ) over $25 \mathrm{~h}$ with suspension extraction mode using SGG-entrapped murine and plant-derived MC10E7 antibodies (for each antibody: $0.5 \mathrm{mg}$ $\mathrm{mAb}$ in $0.5 \mathrm{~g}$ SGG; total mass: $2.5 \mathrm{~g} \mathrm{SGG)}$.

Table 3 Suspension extraction (mode C) of MC-LR from spiked freshwater samples (Windach, $25 \mu \mathrm{g} \mathrm{L}^{-1} ; 1 \mathrm{~L}$ )

\begin{tabular}{lcrcr}
\hline \multicolumn{1}{c}{ Antibody } & Sample & $\begin{array}{c}\text { Depletion } \\
\text { efficiency, } \\
\%\end{array}$ & $\begin{array}{c}\text { Binding } \\
\text { capacity } \\
\%\end{array}$ & $\begin{array}{c}\text { MC-LR } \\
\text { bond } \\
\mu \mathrm{g}\end{array}$ \\
\hline Murine MC10E7 & Windach & 98 & 69 & 24.5 \\
Plant-derived MC10E7 & Windach & 100 & 71 & 25.0 \\
Blank $^{c}$ & Windach & 6 & - & 1.5 \\
\hline
\end{tabular}

a. Binding capacity compared to the theoretical maximum binding capacity.

b. MC-LR bond at the IAE-support (2.5 g of SGG-IAE-support with $2.5 \mathrm{mg}$ of immobilized antibody MC10E7).

c. Non-specific binding at blank SGG.

antibodies but is moreover caused by the better access of immobilized antibodies with suspension extraction (moving adsorbent) in comparison with the packed bed IAE-column experiments. 
Table 4 Suspension extraction (mode C) of MC-LR from spiked freshwater samples (Starnberger See, $100 \mu \mathrm{g} \mathrm{L}^{-1} ; 180 \mathrm{~mL}$ )

\begin{tabular}{lccc}
\hline Depletion & $\begin{array}{c}\text { Depletion } \\
\text { efficiency, \% }\end{array}$ & $\begin{array}{c}\text { Binding } \\
\text { capacity }{ }^{\mathrm{a}}, \%\end{array}$ & $\begin{array}{c}\text { MC-LR bond } \\
\mu \mathrm{g}\end{array}$ \\
\hline 2.21 & 88 & 46 & 15.8 \\
$2.00^{\mathrm{c}}$ & 54 & 25 & 9.7 \\
Blank $^{\mathrm{d}}$ & 13 & - & 2.3 \\
\hline
\end{tabular}

a. Binding capacity compared to the theoretical maximum binding capacity.

b. MC-LR bond at the IAE-column (2.2 $\mathrm{g}$ of SGG-IAE-support prepared with less purified plant-derived antibody fraction).

c. Reusability testing after elution of IAE-support with ACN/water (70:30, v/v).

d. Non-specific binding at blank SGG-support (prepared analogously with protein fraction from untreated tobacco plants).

Removal of MC-LR from freshwater samples: Test with less purified plant-derived antibody preparation

Generally, antibody purification makes use of protein A/G affinity support materials, and is therefore relatively costly, especially if large amounts are required. Consequently, any measures which contribute to a reduction of the total production costs would favor biotechnological use. Aiming at a more economical process for future application, a less purified plantderived antibody preparation was therefore tested as well. It was obtained by a simple extraction of ground tobacco leaf material, followed by the separation of cell debris, and final precipitation using ammonium sulfate. The obtained fresh protein pellet (moist mass of $164 \mathrm{mg}$; estimated specific antibody content $\sim 2.2 \mathrm{mg}$ ) was dissolved in $2 \mathrm{~mL}$ PBS, and the SGG-IAE was prepared as described. For a comparison, we used a blank-SGG obtained with a protein pellet from wild-type plants not producing the recombinant antibody. For depletion, the continuous cyclic sample addition over $18 \mathrm{~h}$ (mode B) was conducted using the spiked surface water sample from Starnberger See as described above. A depletion efficiency of $88 \%$ was obtained, which corresponds to a binding capacity of $46 \%$, compared to the theoretical maximum binding capacity of the estimated antibody mass contained in the protein pellet (Table 4). Hence, the obtained results were very comparable to those obtained with the highly purified plant-derived MC10E7, which revealed a 95\% removal efficiency and a binding capacity of 53\% for freshwater from Starnberger See (Table 2). However, the non-specific binding of MC-LR was approximately doubled $(2.3 \mu \mathrm{g} / 2.2 \mathrm{~g} \mathrm{SGG} v s$. $0.3 \mu \mathrm{g} / 0.5 \mathrm{~g} \mathrm{SGG})$ which was obviously caused by the interaction of microcystin with other plant proteins in the immobilized protein pellet. Summing up, the less purified antibody fraction could be applied without any restriction to toxin removal.

Generally, any multiple use of an immunoaffinity support material is associated with a loss of its binding capacity. The extent depends on the chemical stability of the immobilized antibody and type of eluent required for breaking the antibodyantigen interaction. In the present investigation, $\sim 2 \%$ of bond MC-LR was eluted from an SGG-column with an ACN/water $(70: 30, v / v)$ mixture, which caused only a $20 \%$ loss of the binding capacity in the second application (Table 4). The apparent higher stability of the immobilized plant-based antibody compared to its soluble form against high ACN concentrations might be mainly attributed to the protective effect of the SGG-matrix. Although there are no detailed data available, the gentle fixation within the matrix could partially reduce the ability of the antibody molecules to undergo an irreversible conformational change that would result in a loss of activity.

\section{Conclusions}

We have shown that the sol-gel IAE using anti-MC-LR antibodies is a highly efficient technology for the enrichment of microcystin pollutant from freshwater. This is attributed to the combined effects of the biocompatible silicate polymer and high-affinity antibodies. Our results confirm that this is a green and promising approach, as indicated by the selective and almost complete removal of MC-LR from surface water samples over a five-to-ten hour enrichment time, depending on the use of a column- or suspension-based extraction technique. As expected, the differences observed in preliminary lab-scale studies between murine- and plant-derived IAE-materials are marginal, owing to the fact that both antibodies share the identical binding domain. In excess of analytical application, the possibility to produce the antibody more efficiently, i.e., at higher speed, lower costs and versatility of scalable gene expression in plants compared to the production in cell culture, paves the way for further studies. Additional research is needed to (a) assess the feasibility of the sol-gel immunoaffinity support material (biofilter)-approach at the pilot-scale, which includes scale-up of sample volumes and amounts of antibody-doped IAE-material, (b) further reduce the costs of downstream processing, i.e., use of even less purified antibody fractions for SGG-IAE preparation, and (c) explore and optimize strategies for real world application, e.g., the testing of stationary permeable tube reactors and remediation "rafts" for subsurface floating. As plants are globally accessible and most sustainable, plant-derived antibody production for large-scale application in bioremediation constitutes a very interesting option for both industrialized and developing countries.

\section{Acknowledgements}

The financial support by the Deutsche Forschungsgemeinschaft (DFG) of project KN348/16-1 and by the Austrian Science Fund FWF (I1103) is gratefully acknowledged. We thank Jessica Beyerl, Tim Kratky, Christine Sternkopf and Xaver Hecht for technical assistance.

\section{References}

1. S. J. Moe, S. Haande, and R.-M. Couture, Ecol. Model., 2016, 337, 330.

2. B. Ibelings, J. Fastner, M. Bormans, and P. M. Visser, Aquat. Ecol., 2016, 50, 327.

3. F. Gurbuz, O. Y. Uzunmehmetoğlu, Ö. Diler, J. S. Metcalf, and G. A. Codd, Sci. Total Environ., 2016, 562, 860.

4. W. W. Carmichael, J. Appl. Bacteriol., 1992, 445.

5. WHO, "Water, Sanitation and Health-Guidelines for Drinking Water Quality", Addendum to Vol. 2, Health Criteria and Other Supporting Information, 2nd ed., 1998, Geneva, Switzerland, 83 - 97.

6. S. Hrudey, M. Burch, M. Drikas, and R. Gregory, "Toxic Cyanobacteria in Water: a Guide to Their Public Health Consequences, Monitoring and Management", ed. I. Chorus and J. Bartram, 1999, Chap. 9, World Health Organization, London and New York. 
7. H. C. P. Matthijs, D. Jančula, P. M. Visser, and B. Maršálek, Aquat. Ecol., 2016, 50, 443.

8. L. Triest, I. Stiers, and S. Van Onsem, Aquat. Ecol., 2016, $50,461$.

9. A. R. Shawwa and D. W. Smith, Ozone: Sci. Eng., 2001, 23, 161.

10. B. Nicholson, J. Rositano, and M. Burch, Water Res., 1994, 28, 1297.

11. H. Mash and A. Wittkorn, Water Res., 2016, 95, 230.

12. X. He, A. A. De La Cruz, A. Hiskia, T. Kaloudis, K. O'Shea, and D. D. Dionysiou, Water Res., 2015, 74, 227.

13. X. Zhang, J. Li, J.-Y. Yang, K. V. Wood, A. P. Rothwell, W. Li, and E. R. Blatchley III, Environ. Sci. Technol., 2016, 50, 7671.

14. J. Fan, B.-H . Lin, C.-W. Chang, Y. Zhang, and T. F. Lin, Water Res., 2018, 129, 199.

15. J. Chang, Z.-L. Chen, Z. Wang, J.-M. Shen, Q. Chen, J. Kang, L. Yang, X.-W. Liu, and C.-X. Nie, Water Res., 2014, 63, 52.

16. Y. Gao, F. Wang, Y. Wu, R. Naidhu, and Z. Chen, Chem. Eng. J., 2016, 285, 459.

17. D. Cook and G. Newcombe, Water Sci. Technol., 2002, 2, 201.

18. M. R. Teixeira and M. J., Rosa, Sep. Purif. Technol., 2005, 46, 192

19. S. Pavagadhi, A. I. L. Tang, M. Sathishkumar, K. P. loh, and R. Balasubramanian, Water Res., 2013, 47, 4621.

20. G. Liu, H. Zheng, X. Zhai, and Z. Wang, J. Cleaner Prod., 2018, 176, 463.

21. P. L. Edmiston, K. A. Carter, A. L. Graham, and E. J. Gleason, Sep. Purif. Technol., 2018, 197, 244.

22. J.-A. Park, S.-M. Jung, J.-W. Choi, J.-H. Kim, S. Hong, and A.-H. Lee, Chemosphere, 2018, 193, 883.

23. I. Gagala and J. Mankiewicz-Boczek, Pol. J. Environ. Stud., 2012, 21, 1125.

24. L. A. Lawton and P. K. J. Robertson, Chem. Soc. Rev., 1999, 28, 217.

25. J. L. Bowen, P. Manesiotis, and C. J. Allender, MOLIM, 2013, $1,35$.

26. I. Chianella, M. Lotierzo, S. A. Piletsky, I. E. Tothill, B. Chen, K. Karim, and A. P. F. Turner, Anal. Chem., 2002, $74,1288$.

27. R. B. Queirós, J. P. Noronha, P. V. S. Marques, J. S. Fernandes, and G. F. Sales, Analyst, 2012, 137, 2437.

28. R. J. Krupadam, G. P. Patel, and R. Balasubramanian, Environ. Sci. Pollut. Res., 2012, 19, 1841.

29. S.-D. Pan, X.-H. Chen, X.-P. Li, M.-Q. Cai, H.-Y. Shen, Y.-G. Zhao, and M.-C. Jin, J. Chromatogr. A, 2015, 1422, 1.

30. K. Chen, M. Liu, G. Zhao, H. Shi, L. Fan, and S. Zhao, Environ. Sci. Technol., 2012, 46, 11955.

31. X. Qiu, Y. Liang, and H. Guo, Chin. J. Chromatogr., 2014, 32, 1214.

32. E. A. Mbukwa, T. A. M. Msagati, and B. B. Mamba, Anal. Bioanal. Chem., 2013, 405, 4253.

33. M. Tschofen, D. Knopp, E. Hood, and E. Stoger, Annu. Rev. Anal. Chem., 2016, 9, 71.

34. E. V. Sheshukova, T. V. Komarova, and Y. L. Dorokhov, Biochemistry (Moscow), 2016, 81, 118.

35. G. Edgue, R. M. Twyman, V. Beiss, R. Fischer, and M. Sack, Wiley Interdiscip. Rev.: Nanomed. Nanobiotechnol., 2017, 9, e1462.
36. J. F. Buyel, R. M. Twyman, and R. Fischer, Biotechnol. Adv., 2017, 35, 458.

37. E. K. Miller and W. E. Dyer, Int. J. Phytoremed., 2002, 4, 223.

38. S. Campbell, D. Paquin, J. D. Awaya, and Q. X. Li, Int. J. Phytoremed., 2002, 4, 157.

39. M. Madhurina, M. Bidisha, M. M. Shekhar, C. Sankar, G. Amitava, and M. Arunabha, Int. Res. J. Environment. Sci., 2014, 3, 83.

40. N. K. Hannink, M. Subramanian, S. J. Rosser, A. Basran, J. A. H. Murray, J. V. Shanks, and N. C. Bruce, Int. J. Phytoremediat., 2007, 9, 385.

41. G. Farre, R. M. Twyman, C. Zhu, T. Capell, and P. Christou, Curr. Opin. Biotechnol., 2011, 22, 245.

42. M. Sabalza, B. Miralpeix, R. M. Twyman, T. Capell, and P. Christou, Nat. Biotechnol., 2011, 29, 315.

43. P. M. W. Drake, D. Chargelegue, N. D. Vine, C. J. Van Dolleweerd, P. Obregon, and J. K.-J. Ma, FASEB J., 2002, 16, 1855.

44. P. M. W. Drake, T. Barbi, M. R. Drever, C. J. Van Dolleweerd, A. J. R. Porter, and J. K.-C. Ma, FASEB J., 2010, 24, 882.

45. M. Mergler, K. Wolf, and M. Zimmermann, Appl. Microbiol. Biotechnol., 2004, 63, 418.

46. V. Morath, D.-J. J. Truong, F. Albrecht, I. Polte, R. A. Ciccone, L. F. Funke, L. Reichart, C. G. Wolf, A.-D. Brunner, K. Fischer, P. C. Schneider, J. B. Brüggenthies, F. Fröhlich, G. Wiedemann, R. Reski, and A. Skerra, ACS Synth. Biol., 2014, 3, 990.

47. D. S. Hage, J. Chromatogr. B, 1998, 715, 3.

48. V. Pichon, F. Chapuis-Hugon, and M.-C. Hennion, in "Comprehensive Sampling and Sample Preparation" 2012, Vol. 2, Elsevier, Amsterdam, 359.

49. R. Danczyk, B. Krieder, A. North, T. Webster, H. HogenEsch, and A. Rundell, Biotechnol. Bioeng., 2003, 84, 215.

50. D. Avnir, S. Braun, O. Lev, and M. Ottolenghi, Chem. Mater, 1994, 6, 1605.

51. I. Gill and A. Ballesteros, Trends Biotechnol., 2000, 18, 282.

52. M. Altstein, O. B. Aziz, N. Skalka, A. Bronshtein, J. C. Chuang, and J. M. Van Emon, Anal. Chim. Acta, 2010, 675, 138.

53. R. Gupta and N. K. Chaudhury, Biosens. Bioelectron., 2007, 22, 2387.

54. P. Degelmann, S. Egger, H. Jürling, J. Müller, R. Niessner, and D. Knopp, J. Agric. Food Chem., 2006, 54, 2003.

55. M. Cichna, D. Knopp, and R. Niessner, Anal. Chim. Acta, 1997, 339, 241.

56. S. Melnik, A.-C. Neumann, R. Karongo, S. Dirndorfer, M. Stübler, V. Ibl, R. Niessner, D. Knopp, and E. Stoger, Plant Biotechnol. J., 2018, 16, 27.

57. A. Zeck, A. Eikenberg, M. G. Weller, and R. Niessner, Anal. Chim. Acta, 2001, 441, 1.

58. B. Spitzer, M. Cichna, P. Markl, G. Sontag, D. Knopp, and R. Niessner, J. Chromatogr. A, 2000, 880, 113.

59. M. Schedl, G. Wilharm, S. Achatz, A. Kettrup, R. Niessner, and D. Knopp, Anal. Chem., 2001, 73, 5669.

60. A.-C. Neumann, X. Wang, R. Niessner, and D. Knopp, Anal. Methods, 2016, 8, 57. 